\title{
The Medical Lab Scientist and the Patient
}

\section{Sujatha Siddappa*}

Head of Lab Medicine Graded Autonomy, Institute of Nephrourology, Victoria Hospital

Campus, Bengaluru, India

*Corresponding Author: Sujatha Siddappa, Head of Lab Medicine Graded

Autonomy, Institute of Nephrourology, Victoria Hospital Campus, Bengaluru, India.
Received: March 19, 2020

Published: April 01, 2020

(C) All rights are reserved by Sujatha

Siddappa.
The author penning this down is a Pathologist with administrative offices designate for 25 years. Most or rather a significant number of all the spots of her employment have been with current Webster definition of start-ups. Wherein she has started the division from scratch. For medical professionals this is an unchartered territory where in which there is collaboration of civil works, intellectual property attorneys to human resource management, regulatory professionals, funding organizations basic scientist's and physician scientist's as stake holders. This is a journey of needs of the patient and the team to deliver. One of a very small part is mentioned here to share how small things matter more in instances.

So, this article at the most could be taken as an advice which may not be a "straight jacket" and kind of more synonymous with or rather more in terms of as one would know quote-unquote enter uncharted troublesome/troubled territory. For the author lessons well learnt, accentuate one's workspace with one's learning real time.

Words like self-learning tab disclosure, in other words simply put disclaimer - any resemblances to a real person living or dead is purely coincidental or is it?

Gone, are the days of single conversation or crypt conversation, the need of the hour is paragraph conversation. So, it's kind of social networks, as in, is the author a source of information or are the readers the source of information?

For most, running a department independently is terrifyingly chaotic, especially in the early years.

Over the years the author has reached a situation where a categorical statement could be made by pedantically saying that the organizations need to have more of what I have to offer. The impact you make on how you want people to feel and explore the consciousness to take on vulnerability, flexibility, self-expression you know, kind of swimming in a shark tank. It's like, you know, I am not perfect, but, why are you so mean, catch me if you can, nobody here is simply here - lost in translation - the most difficult thing that happens is that you go to war with the army at hand and not the army you want. The opportunity to learn is more important. As Aristotle, the Greek philosopher put it " For the things we have to learn before we can do them, is but by doing them".

Working ethos - collaboration and agility and the artful management of rather different conversations such as employee feedback in their personalized work experience. Like, performance feedback which is connected to their skills with regard to their work performance, management, mostly evidence based and unambiguous.

So, this is the background which one needs to evaluate and infer from the work bench to the patient This can only happen with genuine deep people empathy and not by faking caring. A few lessons for a department with resource constraints and economics and the cutting-edge special tests in histopathology, like marker study.

Things to be considered

To begin with, the rule of thumb or the rule of two "H". It's got a high cost per test and its high turnaround time.

The interesting thing to be noted is that, quality is a habit, so, it's a thought or mindset which requires effort. If quality is not a need it's a want and if not met then the whole process will be sub optimal.

The marker is an afterthought or a requirement after routine histology. This leads to limited left-over tissue in the block. 
How do we overcome this barrier? is there a solution?

Tumor - The histopathology work bench - trimming deeper till the pathologist is satisfied with his/her report and only then do they think of markers, but, if we are ready, we can plan the tissue retaining better, because lack of tissue makes the surgeon and patient at a culled sac situation. This later leads to complication because if we do not and cannot have adequate tissue for bio marker which come under the preview of preanalytical tissue. Standardization is kind of difficult because the dynamics is different for different labs, albeit, that they are doing the same tests. The subtlety of the tests lies therein.

It's a siloed discipline like or akin to the well-kept secrets of sorcery as to why low biomarker testing rates, low reimbursements and reports run in pages instead of paragraph conversation and the reader has to infer that there is no impression but observation. We see individualist reports, however there is no uniformity. We also see standard reports from the best places which shows - oneline cryptic note which says QNS quantity not sufficient.

This would be a difficult spot for the patient and difficult for anyone who is looking for advanced treatment.

Without further delay, so what are we looking at?

Limited tissue - so we are looking at economy in a situation where there is no lifeline.

The surgeon's perspective biopsy is dependent on size and location - as in access to the lesion. Laboratory bench-Rule out block exhaustion, color code the tissue block, limit the IHC stains and diagnosis with minimal markers - be frugal, optimal approach of 20 unstained slides with serial sections with a 30 days shelf life.

The point the author has made may be a small sample where simple appropriate team approach would lead to revolutionizing the entire system.

Would conclude by saying that "administration" is not a job description but a skill which is cautiously cultivated over the years.

Gratitutude to satya sai institute of higher medical sciences, the Appollo group, Manipal group of Hospitals, Institute of nephrourology. Author is an alumnus of Kempegowda institute of medical sciences and MAHE. Suresh gyan vihar university. Last but not the least to all her teachers. She holds diploma in human resource management, fundamental rights Indian penal code, pain and palliative care medicine and waste management and health care management My appreciation towards fine tuning the article goes out to my colleagues Dr vinay K.S. and Smt Berliya. R.

\section{Assets from publication with us}

- Prompt Acknowledgement after receiving the article

- Thorough Double blinded peer review

- Rapid Publication

- Issue of Publication Certificate

- High visibility of your Published work

Website: www.actascientific.com/

Submit Article: www.actascientific.com/submission.php

Email us: editor@actascientific.com

Contact us: +919182824667

Citation: Sujatha Siddappa. "The Medical Lab Scientist and the Patient". Acta Scientific Cancer Biology 4.5 (2020): 01-02. 